\title{
EDITORIAL
}

\section{Why Isn't It Better?}

\author{
Jobn H. Wasson, MD \\ Department of Community and Family Medicine, Dartmouth Medical School, Hanover, NH
}

Ann Fam Med 2004;2:292-293. DOI: 10.1370/afm.217.

$\mathrm{I}$ $\mathrm{n}$ the past 30 years health service research has described how health care can be made better. ${ }^{1}$ Despite this unprecedented knowledge, health care remains seriously deficient in many ways. ${ }^{1-3}$ Why isn't it better?

When asked that question, physicians most frequently contend that external regulations, medication costs, and lack of time for patient care are the problems. ${ }^{4}$ But most of us know that we health professionals contribute to the blight as well. Health care isn't better because we have not designed the systems to deliver exactly what people want and need exactly when they want and need it. Our systems are more often a product of history and self-interest than of a design that matches our clinical resources to patient needs.

Inadequate systems keep us from doing what we ought to do (the most common oversight) or cause us to do things we ought not to have done (the most visible errors). ${ }^{5}$ Several articles in this issue of the Annals of Family Medicine examine our oversights and errors. ${ }^{6-8}$ Their findings are similar in most ways to studies of medical malpractice in the outpatient setting: lurking among most errors and harms is poor communication. ${ }^{9}$ A typical verbatim among the thousands of outpatient-reported harms reads: "Doctor did not listen to me regarding a medical problem and insisted that it was something else. Gave me prescription that burned my skin and caused great swelling. Could have been avoided if doctor had listened." These comments reflect a mix of issues, but they almost always mention, in one way or another, poor communication. ${ }^{10} \mathrm{We}$

Conflicts of interest: none reported

\section{CORRESPONDING AUTHOR}

John H. Wasson, MD

Department of Community and Family Medicine

Dartmouth Medical School

HB 7265

Hanover, NH 03755

John.Wasson@Dartmouth.edu health professionals and our patients are just not on the "same page."

How are we going to deal with these deficiencies given the realities of the demands on our practices? The answer from the experts is that if we want to be on the same page with our patients, we need to be aware, think smart, and think system.

Being aware is the focus of the articles in this edition the Annals of Family Medicine.

Thinking smart requires us to recognize that the more we help our patients become better at self-care, the better their outcomes and the fewer the harms. ${ }^{11-13}$ We all have our good self-managing patients who show us their medication list and gently correct us when we are about to do something wrong. They live with their illnesses and manage their lives, medications, and tests. Across the nation about $40 \%$ of adult outpatients claim to be good at self-care. The rates of reported harms are lowest among chronic disease patients who report good self-management skills and report that they have received excellent explanations from their doctor $(0.5$ harms per 100 patients per year); patients with poor self-management skills who report inadequate communication have the highest rates of harms (9 harms per 100 patients per year). ${ }^{10}$ Helping poor self-managers become better and confident self-managers become more competent seems to be a good way to fix many health care deficiencies.

Thinking system requires us to use every technique and process possible to ensure that we are on the same page. It can begin when vital signs are recorded in the office. ${ }^{14}$ It can be augmented by the use of interaction technologies designed specifically for busy office practitioners and their patients. ${ }^{10}$ Same-page care can be supported by e-mail, shared medical appointments, ${ }^{15}$ proactive telephone contact, ${ }^{16,17}$ advanced access, ${ }^{18}$ and, of course, continuity of care. ${ }^{19}$ The challenge for us is to systematize same-page care.

I believe that thinking smart and thinking system can be easily retrofitted into most busy practices. ${ }^{20}$ But even if the retrofit is not easy for some, it is essential 
that practices take action. "We are causing harm, and we need to stop it," Don Berwick says. I hope that readers of this issue are as impatient as Don. Let's all make it all better.

To read or post commentaries in response to this article, see it online at http://www.annfammed.org/cgi/content/full/2/4/292.

Key words: Primary health care; patient satisfaction; risk management; patient-centered care; physician-patient relations

Submitted June 6, 2004; accepted June 9, 2004

\section{References}

1. Institute of Medicine. Committee on Quality of Health Care in America. Crossing the Quality Chasm: A New Health System for the 21st Century. Institute of Medicine. Washington DC: National Academy Press; 2001.

2. Kohn LT, Corrigan J, Donaldson MS. Institute of Medicine. Committee on Quality of Health Care in America. To Err Is Human. Building a Safer Health System. Institute of Medicine. Washington DC: National Academy Press; 2000.

3. Blendon RJ, Schoen C, DesRoches CM, Osborn R, Zapert K, Raleigh E. Confronting competing demands to improve quality: a five-country hospital survey. Health Aff (Millwood). 2004;23:119-135.

4. Blendon RJ, Schoen C, Donelan K, et al. Physicians' views on quality of care: a five-country comparison. Health Aff (Millwood). 2001;20:233-243.

5. Woolf SH. Patient safety is not enough: targeting quality improvements to optimize the health of the population. Ann Intern Med. 2004;140:33-36.

6. Woolf SH., Kuzel AJ, Dovey SM, Phillips RL Jr. A string of mistakes: the importance of cascade analysis in describing, counting, and preventing medical errors. Ann Fam Med. 2004;2:317-326.
7. Fernald DH, Pace WD, Harris DM, West DR, Main DS, Westfall JM Event reporting to a primary care patient safety reporting system: a report from the ASIPS collaborative. Ann Fam Med. 2004;2:327-332.

8. Kuzel AJ, Woolf SH, Gilchrist VJ, et al. Patient reports of preventable problems and harms in primary health care. Ann Fam Med. 2004;2:333-340.

9. Levinson W, Roter DL, Mullooly JP, Dull VT, Frankel RM. Physicianpatient communication: the relationship with malpractice claims among primary care physicians and surgeons. JAMA. 1997;277:553-559

10. HowsYourHealth.org Web site. Available at: http://howsyourhealth.org

11. Bodenheimer T, Wagner EH, Grumbach K. Improving primary care for patients with chronic illness. The chronic care model, part two. JAMA. 2002;288:1909-1914.

12. Renders CM, Valk GD, Griffin SJ, Wagner EH, van JTE, Assendelft WJJ. Interventions to improve the management of diabetes in primary care, outpatient, and community settings: a systematic review. Diabetes Care. 2001;24:1821-1833.

13. Bodenheimer $\mathrm{T}$, Lorig $\mathrm{K}$, Holman $\mathrm{H}$, Grumbach $\mathrm{K}$. Patient self-management of chronic disease in primary care. JAMA. 2002;288:2469-2475.

14. Wasson JH, Godfrey MM, Nelson EC, et al. Planned care in microsystems: part 4. Joint Comm J Qual Imp. 2003;29:227-237

15. American Academy of Family Physicians. Practice Management. Available at: http://www.aafp.org/x14713.xml

16. Dietrich, Allen J. The telephone as a new weapon in the battle against depression. Effect Clin Pract. 2000;4:191-193.

17. Wasson J, Gaudette C, Whaley F, Sauvigne A, Baribeau P, Welch HG. Telephone care as a substitute for routine clinic follow-up. JAMA. 1992;267:1788

18. Murray M, Bodenheimer T, Rittenhouse D, Grumbach K. Improving timely access to primary care: case studies of the advanced access model. JAMA. 2003;289:1042-1046.

19. Wasson JH, Sauvigne AE, Mogielnicki RP, et al. Continuity of outpatient medical care in elderly men. A randomized trial. JAMA. 1984;252:2413-2417.

20. Improve your Medical Care Web site. Available at: www.improveyourmedicalcare.org. 